\title{
Risks Posed to Corneal Transplant Recipients by COVID-19-Affected Donors
}

\author{
Jordan D. Desautels · Majid Moshirfar (D) - Tanisha Martheswaran • \\ Kathryn M. Shmunes • Yasmyne C. Ronquillo
}

Received: April 21, 2020 / Published online: May 6, 2020

(C) The Author(s) 2020

\section{ABSTRACT}

The recent emergence of the novel severe acute respiratory syndrome coronavirus 2 (SARS-CoV2) and its resultant human disease, COVID-19, will likely have a significant impact on the corneal tissue donor pool. Current recommendations from the United States and global eye bank associations call for the outright avoidance of tissues from donors recently infected with or exposed to COVID-19. This conservative recommendation is currently appropriate given the reported ocular sequelae, tear film viral detectability, and transmissibility of COVID-19. However, the rapidly increasing global

Digital Features To view digital features for this article go to https://doi.org/10.6084/m9.figshare.12179220.

J. D. Desautels

The Warren Alpert Medical School of Brown

University, Providence, RI, USA

M. Moshirfar ( $\square)$ · K. M. Shmunes · Y. C. Ronquillo Hoopes Vision Research Center, Draper, UT, USA e-mail: Cornea2020@me.com

M. Moshirfar

John A. Moran Eye Center, University of Utah

School of Medicine, Salt Lake City, UT, USA

M. Moshirfar

Utah Lions Eye Bank, Murray, UT, USA

T. Martheswaran

Department of Stem Cell and Regenerative Biology,

Harvard University, Cambridge, MA, USA prevalence and mortality of COVID-19 threatens the tenability of current tissue exclusion guidelines, and may necessitate their relaxation in the near future.

Keywords: Cornea donation; Corneal transplant; Coronavirus; COVID-19; Penetrating keratoplasty; SARS-Cov-2; Severe acute respiratory syndrome; Tissue donation; Viral pandemic; Viral transmission

\section{BACKGROUND}

The unprecedented global spread of the novel severe acute respiratory syndrome coronavirus 2 (SARS-CoV-2) and its resultant cardiopulmonary disease, COVID-19, has radically altered a multitude of global practices. As we seek the appropriate adjustments to the practice of ophthalmology, we will be constantly challenged to both confront the current disease burden and shape its future curvature. In doing so, we must incorporate a knowledge base that is both as young and dynamic as the pandemic itself. Additionally, we must be prepared to serve the emergent needs of the population in as safe a manner as possible. A significant issue at present is the inevitable interaction of the cornea donor pool with SARS-CoV-2. Even with our currently limited testing capacity, the confirmed US and global case numbers are 
Table 1 Current corneal donation parameters from selected governing bodies

\begin{tabular}{|c|c|}
\hline Eye Bank Association of America (EBAA) [3] & Global Alliance of Eye Bank Associations (GAEBA) [4] \\
\hline $\begin{array}{l}\text { - Tested positive for or diagnosed with COVID-19 within } \\
\text { the past } 2 \text { months } \\
\text {-Acute respiratory illness (fever }>100.4^{\circ} \mathrm{F}\left(38^{\circ} \mathrm{C} \text { ) and at }\right. \\
\text { least one severe common symptom of respiratory disease } \\
\text { with no other etiology that fully explains the clinical } \\
\text { presentation within the last } 28 \text { days } \\
\text {-Close contact with a person who has confirmed COVID-19 } \\
\text { infection or with a person under investigation (PUI) (as } \\
\text { defined by the CDC) within the last } 28 \text { days } \\
\text {-Travel to or transit through a foreign country identified by } \\
\text { the CDC as a level } 2 \text { or } 3 \text { travel risk within the last } 28 \text { days } \\
\text {-ARDS [acute respiratory distress syndrome], pneumonia or } \\
\text { pulmonary computed tomography (CT) scanning showing } \\
\text { "ground glass opacities" (regardless of whether another } \\
\text { organism is present) within the last } 28 \text { days }\end{array}$ & $\begin{array}{l}\text {-Excluded from donation } \\
\text {-Less than } 14 \text { days since resolution of symptoms due to } \\
\text { confirmed coronavirus infection } \\
\text {-Awaiting test results for suspected coronavirus infection } \\
\text {-Less than } 14 \text { days from the first day of contact with an } \\
\text { individual with a confirmed or suspected infection } \\
\text { Discretionary donation } \\
\text {-Confirmed infection. If more than } 14 \text { days have passed } \\
\text { since resolution of symptoms } \\
\text {-If more than } 14 \text { days since the first day of contact with an } \\
\text { individual with a confirmed or suspected infection, and the } \\
\text { donor remained well, with no symptoms of coronavirus } \\
\text { infection } \\
\text {-If less than } 14 \text { days and the donor remained well, with no } \\
\text { symptoms of coronavirus infection-subject to individual } \\
\text { risk assessment } \\
\text {-Donors without respiratory symptoms who are not } \\
\text { suspected to have, and have not been tested for, COVID- } \\
\text { po infection, and who were in intensive care units with } \\
\text { patients who had been tested for COVID-19 infection and } \\
\text { assessment }\end{array}$ \\
\hline
\end{tabular}

significant, and trending towards an unknown peak [1]. The number of recent case contacts is further expected to be significantly higher than the total confirmed case number. The current annual US all-cause mortality rate is approximately 867 per 100,000 [2]. In addition to deaths directly caused by COVID-19, it is expected that a significant number of individuals dying from all other causes will be infected by or exposed to COVID-19. It is therefore probable that a sizable fraction of donated corneas will soon meet a donation exclusion parameter set out by a tissue banking governing body (Table 1).

Current guidance from the Eye Bank Association of America (EBAA) and the Global Alliance of Eye Bank Associations (GAEBA) is crafted in a prudently conservative manner that largely excludes donors positive for, or in recent close contact with, COVID-19 [3, 4]. These recommendations are congruent with U.S. Food and Drug Administration (FDA) guidance on human cell, tissue, and cellular or tissue-based products $(\mathrm{HCT} / \mathrm{P})$, which call for careful consideration of whether HCT/P donors have been infected or in contact with COVID-19 within the past 28 days. The FDA guidelines further indicate that there is currently no evidence for transmission of respiratory viruses in general through tissue transplantation, implantation, or infusion, and therefore do not recommend tissue banking establishments use additional laboratory screening for asymptomatic HCT/P donors. [5]. 
In the US alone in 2018, all-cause mortality claimed the lives of approximately 2.8 million residents [2]. Of these deaths, 168,569 were determined eligible for corneal donation by the EBAA, and 123,222 corneas were ultimately recovered and banked for intended transplant. Thus, even prior to the COVID-19 pandemic, an already small proportion of potential donor corneas make it to the donor pool after being filtered through a series of stringent eligibility criteria that include several viral contraindications [6].

At present, the EBAA excludes corneas from donors affected by HIV types 1 and 2, hepatitis $\mathrm{B}$ virus (HBV), hepatitis C virus (HCV) herpes simplex virus (HSV), human T-cell lymphotropic virus (HTLV)-1, HTLV-2, rabies, West Nile, vaccinia, Zika, and Ebola virus disease (EVD). Other communicable agents that may be transmitted by ocular tissue and pose a risk to recipients and tissue handlers or have insufficient evidence of risk are also excluded, especially if such agents possess the potential for a high prevalence in the donor pool [7].

These exclusion criteria are based on an approach that attempts to weigh the risks of a virus's transmissibility, prevalence, and recipient effects. Exclusion criteria are easily drawn for viruses such as HSV, which is transmissible through penetrating keratoplasty (PK), is prevalent in the general population, and is a known contributor to primary graft failure (PGF) [8-10]. Although low in prevalence, rabies virus bears a similar risk profile to HSV in that it has known transmissibility through corneal transplantation and a significant potential host effect $[11,12]$. Some viruses with no known transmissibility through corneal donation, such as HIV, HCV, and West Nile virus, are excluded for their potentially devastating recipient effects and transmissibility by non-ocular routes, even in the absence of observed transmissibility through corneal donation [8]. Additionally, for HIV, corneal epithelial detection alone has been sufficient to raise concern for corneal donation [13], even in the absence of seroconversion in corneal recipients from known HIV-positive donors, and a known lack of transmissibility through ocular tissues or tears [8, 14-17]. Conversely, donor cytomegalovirus (CMV) infection does not preclude corneal donation, even though CMV affects up to $60 \%$ of the US population [18], can be transmitted through corneal donation, presents low but unclear risks for PGF $[19,20]$, and can be problematic for immunosuppressed recipients [21, 22]. This is likely due to a lack of significant recipient effect in a vast majority of cases and ease of treatment with antivirals [19]. Adenovirus affected individuals without keratitis are similarly not excluded due to a lack of significant recipient effect, despite its high prevalence and role in keratoconjunctivitis in the general population. Influenza virus, too, is not a current eye banking exclusion parameter despite being a significant cause of global morbidity and mortality. In the 2018-2019 flu season, 34,200 people died from viral influenza in the US alone, generating 68,400 total corneas. [23]. Approximately 5.6 million corneas were generated by all-cause mortality in the US in 2018, $123,122(2.2 \%)$ of which ultimately met EBAA eligibility and were recovered for intended transplant. At a rate of $2.2 \%$, an estimated 1500 corneas from influenza-deceased individuals were potentially recovered for intended transplant in the US in 2018. In reality, this number is likely lower due to EBAA exclusion of deaths due to sepsis. Although COVID-19 is a considerably more significant pandemic than the current influenza burden, influenza remains a valid example of a deadly, primarily respiratory, virus that is capable of causing conjunctivitis and is detectable by conjunctival swabbing [24]. Despite the potential illness severity of influenza, corneas generated by non-septic influenza deaths are still considered suitable for donation, and have not been shown to pose a significant risk to corneal tissue recipients.

The exclusion of SARS-CoV-2-affected corneas from the donor pool is appropriate at present given its relatively high transmissibility, possible conjunctival presence, and the possible severity of resultant infection. However, while the exclusion of individuals infected with or exposed to COVID-19 from the donor pool may be currently appropriate, the rate of spread of this disease, in conjunction with its relatively high mortality, may unfortunately preclude the outright avoidance of this potentially vast 
donor pool moving forward. Moreover, while tissue availability is currently sufficient in the US, especially with reductions in non-essential operative volume, the avoidance of COVID-19affected tissues could disproportionally affect import-reliant countries that source tissues from surplus nations [25].

It is therefore imperative that we characterize the theoretical risks posed to recipients of corneas from COVID-19-affected donors so that informed decisions can guide practice in the midst of this pandemic. In this article, we attempt to frame a discussion about the theoretical risks of transplanting corneal tissue from donors infected with or exposed to COVID-19, by compiling lessons from prior global coronavirus outbreaks and describing what is currently known about the interaction of this disease with ocular tissues. While relevant and highly important, the additional risks posed to tissue recovery personnel, eye bank staff, and surgeons are outside of the scope of this article. Furthermore, this article is based on previously conducted studies and does not contain any studies with human participants or animals performed by any of the authors.

\section{PRESENCE OF SARS-COV-2 IN THE TEAR FILM AND CONJUNCTIVAL SECRETIONS}

Studies indicating the potential for SARS-CoV-2 to affect the tear film, albeit with low frequency, have produced concerning implications for corneal tissue donation. Although COVID-19 is far and away dominated by cardiopulmonary symptomatology, there are preliminary reports of coinciding ocular symptoms. A case series of 38 COVID-19-positive patients in Hubei Province, China, showed that 12 of these patients experienced symptoms of conjunctivitis during hospitalization, which occurred predominantly in patients with severe systemic disease. Eleven of the 12 patients with ocular symptoms had positive reverse-transcriptase polymerase chain reaction (RT-PCR) evidence of virus in the nasopharynx. Two of these 11 patients also had conjunctival RT-PCR evidence of disease [26]. Importantly, conjunctival injection and irritation could be secondary symptoms of the ventilatory setups used for these patients, and only one patient presented with conjunctivitis as an initial sign. In another series of 30 confirmed COVID-19 pneumonia patients, Xia et al. showed positive RT-PCR evidence of virus in tear and conjunctival secretions in a patient who also had active conjunctivitis. All other samples collected from the remaining 29 patients were negative, and remained so on repeat testing 2-3 days later [27]. More recently, Jun and colleagues showed no viral presence by RT-PCR in 64 tear film samples from 17 COVID19-positive patients-one of whom developed conjunctival injection and chemosis during hospitalization [28]. Additional, less rigorously reported observational data in 114 patients hospitalized with COVID-19 in China did not yield a single detected instance of conjunctival SARS-CoV-2 presence [29].

Prior experience with the 2003 outbreak of the highly homologous severe acute respiratory syndrome coronavirus (SARS-CoV) also showed rare conjunctival detection. However, it indicated that viral tear film detection may be timedependent and can occur in the absence of conjunctivitis [30]. During this outbreak, Loon et al. positively detected virus by RT-PCR in tear samples from three out of eight patients with serology-confirmed SARS and without conjunctivitis. Notably, all three positive detections occurred within 9 days of disease onset (mean: $4 \pm 3.2$ days). The five remaining serologyconfirmed cases did not show evidence of viral matter in their tear films, but overall, were tested at a later time (mean $19.4 \pm 11.2$ days). It is unclear whether the three initially positive patients were tested for viral clearance from the tear film at a later interval. Additional studies from the 2003 SARS outbreak, however, showed no detection of virus in either tears or conjunctival samples from 17 patients with confirmed SARS [31]. Importantly, while these negative series may indicate a truly low incidence of viral presence in the tear film and conjunctiva, RT-PCR has low sensitivity for viral detection in such samples [32]. These series are ultimately limited by their small sizes, and can only inform us that (1) SARS-CoV-2 is likely rarely present in the tear film and conjunctival 
secretions of COVID-19-positive patients, and (2) based on prior experience, tear film viral presence may be independent of signs of conjunctivitis.

If a SARS-CoV-2 viral load can be detected in the tear film and conjunctiva, three theoretical mechanisms could be at play. First, viral particles contained in respiratory droplets could be deposited onto and confined to the patient's tear film by their own respiration or that of a nearby positive individual. In this case, the ocular tissue itself would not be affected, and corneal donation would not present significant risks to the host. Second, viral particles could be shed into the tear film by infected epithelial or even deeper corneal stromal cells. If valid, this would present a higher risk for ocular tissue donation. Third, systemic infection could manifest diffusely and be detectable in ocular tissues, though this seems less likely given the overall rarity of ocular detectability. The second possibility of tear film detection based on an underlying ocular cellular infection seems the most plausible, given the seeming co-occurrence of tear film detectability and conjunctivitis. Data suggesting the involvement of deeper ocular structures are highly limited, but it remains theoretically possible, given the cellular entry mechanism of SARS-CoV-2 [33]. Regardless of the mechanism, the potential presence of SARS-CoV-2 in the tear film and/or conjunctiva has implications for transplant recipients of COVID-19-affected corneas due to the potential for ocular transmission.

\section{OCULAR TRANSMISSIBILITY AND IMPLICATIONS FOR CORNEA DONATION}

Many coronaviruses are capable of causing fulminant respiratory disease through ocular mucosal entry and subsequent spread through the nasolacrimal system [34]. This possibility has been popularized by anecdotal evidence of a healthcare worker contracting COVID-19 while wearing otherwise full personal protective equipment (PPE) without ocular protection, and has raised concerns surrounding contact lens use [35].
Interestingly, the possibility remains that conjunctivitis and/or viral detection in the tear film may require viral entry into the eye, which may or may not be the predominant cause of systemic infection. Preliminary and limited data from intentional exposure of three rhesus macaques to SARS-CoV-2 via an isolated ocular conjunctival route versus an isolated intratracheal route has shown varying infectious patterns [33]. The two macaques that the authors infected by an ocular-conjunctival route had detectable viral loads in conjunctival swabs on post-infection day 1 that could no longer be detected on post-infection day 3 . The single macaque infected by an intratracheal route never developed conjunctival detectability. All monkeys experienced COVID-19 respiratory disease. Interestingly, however, after the monkeys were euthanized and necropsied on postinfection day 7 , the monkeys infected by the conjunctival route had a weakly detectable viral load in the lacrimal gland, optic nerve, and conjunctival tissues, and a strongly detectable viral signal in upper respiratory and pulmonary tissues. The intratracheally exposed monkey had no detectable ocular viral load; however, virus was strongly expressed in the pulmonary and gastrointestinal systems. Despite limitations in the sample size and species of this study, it suggests that COVID-19positive patients infected by an ocular route may have initial conjunctival detectability that clears early in the course of infection, but may additionally have viral particles within deeper ocular tissue structures at later time points. Corneal stromal tissue, however, was not identified as a location of viral detectability. What remains to be determined is the risk that these examples of ocular RNA detectability will play in corneal donation. The nucleic acids of other viruses, such as adenovirus and $\mathrm{CMV}$, can be detected in banked corneal tissues [36] without a significant reactivation or infection risk in immunocompetent recipients.

While the harboring of SARS-CoV-2 particles within deeper ocular tissues remains speculative and theoretical, it is important to consider the mechanism by which this phenomenon could occur, given its implications for corneal tissue donation. Entry of SARS-CoV-2 into a host cell 
relies on the interaction between the viral envelope spike (S) protein and the host cell angiotensin-converting enzyme 2 (ACE2) receptor [37]. This entry mechanism is homologous to that of the earlier SARS-CoV [38]. The Middle East respiratory syndrome coronavirus (MERS-CoV), by contrast, utilizes the dipeptidyl peptidase 4 (DPP4) receptor to facilitate viral entry [39]. The function of ACE2 is primarily to convert angiotensin II generated by angiotensin-converting enzyme (ACE) to angiotensin (1-7) [40]. As such, it more broadly functions as part of the renin-angiotensin system (RAS) to modulate vascular tone and systemic blood pressure. In humans, ACE2 is strongly expressed in the gastrointestinal tract, heart, kidneys, and type II alveolar cells of the lungs, explaining the predominant clinical effect of COVID-19 disease on these systems [41]. Nevertheless, the presence of a locally acting ocular renin-angiotensin system is well described, and the expression of ACE2 in a variety of ocular tissues may yield a pathway by which SARS-CoV-2 is harbored within these tissues, and may not remain confined to the tear film.

Currently identified ocular localizations of ACE2 include the aqueous humor [42], retina [43], conjunctiva, and cornea [44]. Porcine studies have also revealed ACE2 expression in the ciliary body and vitreous [45]. Following the first SARS outbreak, it was shown using in vitro studies that the surface $S$ protein of SARS-CoV interacts, albeit weakly, with ACE2 on human conjunctival epithelial cells, conjunctival fibroblasts, and corneal epithelial cells [44]. Interaction of the $S$ protein with corneal stromal cells was not described. Overall, there is currently no evidence that the SARS-CoV-2 virus infects deeper corneal tissues in patients with COVID-19, and this possibility remains merely theoretical based on animal and prior in vitro studies.

\section{CONCLUSIONS}

Based on the current literature, COVID-19 is a predominantly respiratory process that has ocular manifestations limited to mild conjunctivitis in a very small percentage of individuals.
The rare incidence of conjunctivitis and ocular viral detectability leaves a large COVID-19-affected donor pool without any evidence of ocular involvement. While it is possible that viral RNA can be detected in the conjunctival tear film, and that the necessary viral cellular integration machinery exists within donor tissues, we currently lack sufficient evidence to suggest that a sizable viral load presenting a significant risk to donor recipients is harbored within the corneal stroma. The suspected confinement of this virus to surface or near-surface ocular structures also increases the theoretical degree of sterilization provided by povidoneiodine (PVD-I) applied to the corneal surface after donor excision [46, 47]. However, we remain aware that PVD-I does not accomplish complete sterilization, and by no means eliminates the possibility of viral retention within ocular structures [36]. Furthermore, we recognize that although only theoretical based on current literature, infection of deeper cellular layers of corneal donor tissue remains a possibility, and warrants additional study. As such, we understand and endorse the current EBAA and GAEBA guidelines while tissue availability and export capabilities remain. However, we also envision a rapidly approaching reality wherein the population penetrance of COVID19 becomes sufficiently high as to force our hand in banking and utilizing tissues affected by its reach, especially as more positive cases are identified by improvements in testing capacity. We feel that, overall, the risk of transmission through corneal stromal tissue is low, and that donors affected by COVID-19 may potentially come to be treated in the same fashion as individuals who succumb to non-septic terminal respiratory complications of viral influenza. Moreover, the likelihood that COVID-19-affected donor tissues are already being utilized due to false-negative tests, lags or lapses in screening, and a prolonged asymptomatic disease latency in some individuals is high. It is thus imperative going forward that we implement mechanisms to correlate COVID-19 status in donors and recipients, look for evidence of virus in corneal samples from deceased COVID19-positive individuals, and determine evidence-based donation waiting periods as we 
come to understand the implications of viral RNA detection for transmissibility.

\section{ACKNOWLEDGEMENTS}

Funding. This study was funded by an unrestricted grant from Research to Prevent Blindness (RPB), New York, NY.

Authorship. All named authors meet the International Committee of Medical Journal Editors (ICMJE) criteria for authorship for this manuscript, take responsibility for the integrity of the work, and have given final approval to the version to be published.

Disclosures. Jordan D. Desautels, Majid Moshirfar, Tanisha Martheswaran, Kathryn M. Shmunes, and Yasmyne C. Ronquillo have no conflict of interest related to this work.

Compliance with Ethics Guidelines. This article is based on previously conducted studies and does not contain any studies with human participants or animals performed by any of the authors.

Data Availability. Data sharing is not applicable to this article, as no data sets were generated or analyzed during the current study.

Open Access. This article is licensed under a Creative Commons Attribution-NonCommercial 4.0 International License, which permits any non-commercial use, sharing, adaptation, distribution and reproduction in any medium or format, as long as you give appropriate credit to the original author(s) and the source, provide a link to the Creative Commons licence, and indicate if changes were made. The images or other third party material in this article are included in the article's Creative Commons licence, unless indicated otherwise in a credit line to the material. If material is not included in the article's Creative Commons licence and your intended use is not permitted by statutory regulation or exceeds the permitted use, you will need to obtain permission directly from the copyright holder. To view a copy of this licence, visit http://creativecommons.org/licenses/by$\mathrm{nc} / 4.0 /$.

\section{REFERENCES}

1. Dong E, Du H, Gardner L. An interactive web-based dashboard to track COVID-19 in real time. Lancet Infect Dis. 2020. https://doi.org/10.1016/s14733099(20)30120-1 (PMID: 32087114).

2. Xu JQ, Murphy SL, Kochanek KD, Arias E. Mortality in the United States, 2018. NCHS Data Brief, no. 355. Hyattsville, MD: National Center for Health Statistics; 2020.

3. Eye Bank Association of America. COVID-19 Screening Recommendations for EBAA Member Eye Banks. Available at: https://restoresight.org/covid19-updates/. Accessed 30 March 2020.

4. Global Alliance of Eye Bank Associations. ALERT UP-DATE: Coronavirus (COVID-2019) and Ocular Tissue Donation. https://www.gaeba.org/2020/ alert-coronavirus-2019-ncov-and-ocular-tissue-dona tion/. Accessed 25 March 2020.

5. U.S. Food and Drug Administration. Important Information for Human Cell, Tissue, or Cellular or Tissue-based Product (HCT/P) Establishments Regarding the 2019 Novel Coronavirus Outbreak. https://www.fda.gov/vaccines-blood-biologics/safetyavailability-biologics/important-information-humancell-tissue-or-cellular-or-tissue-based-product-hctp-es tablishments. Accessed 14 Feb 2020.

6. Eye Bank Association of America. 2018 Eye Banking Statistical Report. EBAA; 2018. p. 13

7. Eye Bank Association of America. Medical standards. 2019. https://restoresight.org/wp-content/ uploads/2019/11/Med-Standards-October-10-2019. pdf. Accessed 6 Apr 2020.

8. Dubord PJ, Evans GD, MacSai MS, et al. Eye banking and corneal transplantation communicable adverse incidents: Current status and project NOTIFY. Cornea. 2013;32(8):1155-66. https://doi.org/10. 1097/ico.0b013e31828f9d64 (PMID: 23676781).

9. Cleator GM, Klapper PE, Dennett C, et al. Corneal donor infection by herpes simplex virus: herpes simplex virus DNA in donor corneas. Cornea. 1994;13:294-304. https://doi.org/10.1097/000032 26-199407000-00003 (PMID: 7924328).

10. Cockerham GC, Bijwaard K, Sheng ZM, et al. Primary graft failure: a clinicopathologic and 
molecular analysis. Ophthalmology. 2000;107: 2083-90. https://doi.org/10.1016/s01616420(00)00361-4 (PMID: 11054337).

11. Javadi MA, Fayaz A, Mirdehghan SA, et al. Transmission of rabies by corneal graft. Cornea. 1996;15: 431-3. https://doi.org/10.1097/00003226199607000-00014 (PMID: 8776570).

12. Centers for Disease Control and Prevention. Human to human transmission of rabies via a corneal transplant-Thailand. MMWR Morb Mortal Wkly Rep. 1981;30(37):473-4.

13. Caron MJ, Wilson R. Review of the risk of HIV infection through corneal transplantation in the United States. J Am Optom Assoc. 1994;65:173-8 (PMID: 8201168).

14. Pepose JS, MacRae S, Quinn TC, et al. Serologic markers after the transplantation of corneas from donors infected with human immunodeficiency virus. Am J Ophthalmol. 1987;103:798-801. https://doi.org/10.1016/s0002-9394(14)74396-X (PMID: 3296763).

15. Schwarz A, Hoffmann F, L'age-Stehr J, et al. Human immunodeficiency virus transmission by organ donation. Outcome in cornea and kidney recipients. Transplantation. 1987;44:21-4. https://doi. org/10.1097/00007890-198707000-00006 (PMID: 3299918).

16. Simonds RJ, Holmberg SD, Hurwitz RL, et al. Transmission of human immunodeficiency virus type 1 from a seronegative organ and tissue donor. N Engl J Med. 1992;326:726-32. https://doi.org/10. 1056/NEJM199203123261102 (PMID: 1738377).

17. Fujikawa LS, Salahuddin SZ, Palestine AG, et al. Isolation of human T-lymphotropic virus type III from the tears of a patient with the acquired immunodeficiency syndrome. Lancet. 1985;2: 529-30. https://doi.org/10.1016/s01406736(85)90464-7 (PMID: 2412078).

18. Zhang LJ, Hanff P, Rutherford C, et al. Detection of human cytomegalovirus DNA, RNA, and antibody in normal donor blood. J Infect Dis. 1995;171: 1002-6. https://doi.org/10.1093/infdis/171.4.1002 (PMID: 7706776).

19. Suzuki T, Hara Y, Uno T, et al. DNA of cytomegalovirus detected by PCR in aqueous of patient with corneal endotheliitis after penetrating keratoplasty. Cornea. 2007;26:370-2. https://doi.org/10.1097/ ICO.0b013e31802d82fa (PMID: 17413969).

20. Sonoyama H, Araki-Sasaki K, Osakabe Y, et al. Detection of cytomegalovirus DNA from cytomegalovirus corneal endotheliitis after penetrating keratoplasty. Cornea. 2010;29:683-5. https://doi.
org/10.1097/ICO.0b013e3181c325e2

20458221).

(PMID:

21. Koizumi N, Yamasaki K, Kawasaki S, et al. Cytomegalovirus in aqueous humor from an eye with corneal endotheliitis. Am J Ophthalmol. 2006;141: 564-5. https://doi.org/10.1016/j.ajo.2005.09.021 (PMID: 16490509).

22. Maguire MG. Cytomegalovirus transmission and corneal transplantation. Arch Ophthalmol. 1988;106:877. https://doi.org/10.1001/archopht. 1988.01060140019003 (PMID: 2839135).

23. Centers for Disease Control. Estimated Influenza Illnesses, Medical visits, Hospitalizations, and Deaths in the United States-2018-2019 influenza season. https://www.cdc.gov/flu/about/burden/ 2018-2019.html. Accessed 6 Apr 2020.

24. Creager HM, Kumar A, Zeng H, Maines TR, Tumpey TM, Belser JA. Infection and replication of influenza virus at the ocular surface. J Virol. 2018;92(7): e02192-17. https://doi.org/10.1128/JVI.02192-17 (PMID: 29321303).

25. Gain P, Jullienne R, He Z, et al. Global survey of corneal transplantation and eye banking. JAMA Ophthalmol. 2016;134(2):167-73. https://doi.org/ 10.1001/jamaophthalmol.2015.4776 26633035).

(PMID:

26. Wu P, Duan F, Luo C, et al. Characteristics of ocular findings of patients with coronavirus disease 2019 (COVID-19) in Hubei Province, China. JAMA Ophthalmol. 2019. https://doi.org/10.1001/ jamaophthalmol.2020.1291 (PMID: 32232433).

27. Xia J, Tong J, Liu M, Shen Y, Guo D. Evaluation of coronavirus in tears and conjunctival secretions of patients with SARS-CoV-2 infection. J Med Virology. 2020. https://doi.org/10.1002/jmv.25725 (PMID: 32100876).

28. Jun YIS, Anderson DE, Zheng Kang AE, et al. Assessing viral shedding and infectivity of tears in coronavirus disease 2019 (COVID-19) patients. Ophthalmology. 2019. https://doi.org/10.1016/j. ophtha.2020.03.026.

29. Deng C, Yang Y, Chen H, Chen W, Chen Z, Ma K, Wang J. Ocular detection of SARS-CoV-2 in 114 cases of COVID-19 pneumonia in Wuhan, China: an observational study. China Observ Stud. 2020; p 193

30. Loon SC, Teoh SC, Oon LL, et al. The severe acute respiratory syndrome coronavirus in tears. $\mathrm{Br} \mathrm{J}$ Ophthalmol. 2004;88(7):861-3. https://doi.org/10. 1136/bjo.2003.035931 (PMID: 15205225). 
31. Chan WM, Yuen KS, Fan DS, Lam DS, Chan PK, Sung JJ. Tears and conjunctival scrapings for coronavirus in patients with SARS. Br J Ophthalmol. 2004;88(7):968-9. https://doi.org/10.1136/bjo. 2003.039461 (PMID: 15205249).

32. Peiris JSM, Lai ST, Poon LLM, et al. Coronavirus as a possible cause of severe acute respiratory syndrome. Lancet. 2003;361(9366):1319-25. https://doi.org/ 10.1016/S0140-6736(03)13077-2 (PMID: 12711465).

33. Wei D, Linlin B, Hong G, Zhiguang X, Yajin Q, Zhiqi S, Shunran G, Jiayi L, Jiangning L, Pin Y, Feifei Qi Yanfeng $u$, Fengli L, Chong X, Qi L, Jing X, Qiang W, Mingya L, Guanpeng W, Shunyi W, Yu HXL. Rhesus macaques can be effectively infected with SARS-CoV-2 via ocular conjunctival route. BioRxiv. 2020.

34. Belser JA, Rota PA, Tumpey TM. Ocular tropism of respiratory viruses. Microbiol Mol Biol Rev. 2013;77(1):144-56. https://doi.org/10.1128/mmbr. 00058-12 (PMID: 23471620).

35. Lu CW, Liu XF, Jia ZF. 2019-nCoV transmission through the ocular surface must not be ignored. Lancet. 2020. https://doi.org/10.1016/S01406736(20)30313-5 (PMID: 32035510).

36. Broniek G, Langwińska-Wośko E, Sybilska M, Szaflik J, Przybylski M, Wróblewska M. Occurrence of viral DNA in paired samples of corneal rim and cornea preservation fluid. J Med Virol. 2017;89:732-6. https://doi.org/10.1002/jmv.24675

(PMID: 27588373).

37. Zhou P, Yang X-L, Wang X-G, et al. A pneumonia outbreak associated with a new coronavirus of probable bat origin. Nature. 2020;579(7798):270-3. https://doi.org/10.1038/s41586-020-2012-7 (PMID: 32015507).

38. Wang $\mathrm{H}$, Yang $\mathrm{P}$, Liu $\mathrm{K}$, et al. SARS coronavirus entry into host cells through a novel clathrin- and caveolae-independent endocytic pathway. Cell Res. 2008;18(2):290-301. https://doi.org/10.1038/cr. 2008.15 (PMID: 18227861).

39. Raj VS, Mou H, Smits SL, et al. Dipeptidyl peptidase 4 is a functional receptor for the emerging human coronavirus-EMC. Nature. 2013;495(7440):251-4. https://doi.org/10.1038/nature12005

23486063).

(PMID:

40. Patel AB, Verma A. COVID-19 and angiotensinconverting enzyme inhibitors and angiotensin receptor blockers: what is the evidence? JAMA. 2020. https://doi.org/10.1001/jama.2020.4812 (PMID: 32208485).

41. Zhou F, Yu T, Du R, et al. Clinical course and risk factors for mortality of adult inpatients with COVID-19 in Wuhan, China: a retrospective cohort study. Lancet. 2020;S0140-6736(20):30566-3. https://doi.org/10.1016/S0140-6736(20)30566-3

(PMID: 32208485).

42. Holappa M, Vapaatalo H, Vaajanen A. Many faces of renin-angiotensin system-focus on eye. Open Ophthalmol J. 2017;11(1):122-42. https://doi.org/ $10.2174 / 1874364101711010122$ 28761566).

(PMID:

43. Senanayake P, Drazba J, Shadrach K, et al. Angiotensin II and its receptor subtypes in the human retina. Invest Ophthalmol Vis Sci. 2007;48(7): 3301-11. https://doi.org/10.1167/iovs.06-1024 (PMID:17591902).

44. Sun Y, Liu L, Pan X, Jing M. Mechanism of the action between the SARS- CoVS240 protein and the ACE2 receptor in eyes. Int J Ophthalmol. 2006;6(4): 783-6.

45. Luhtala S, Vaajanen A, Oksala O, Valjakka J, Vapaatalo H. Activities of angiotensin-converting enzymes ACE1 and ACE2 and inhibition by bioactive peptides in porcine ocular tissues. J Ocul Pharmacol Ther. 2009;25(1):23-8. https://doi.org/ 10.1089/jop.2008.0081 (PMID: 19232015).

46. Eye Bank Association of America. 2019 Procedures Manual. Available at: https://restoresight.org/wpcontent/uploads/2019/11/EBAA-ProcMan-October2019.pdf. Accessed 6 Apr 2020.

47. Kampf G, Todt D, Pfaender S, Steinmann E. Persistence of coronaviruses on inanimate surfaces and their inactivation with biocidal agents. J Hosp Infect. 2020;104(3):246-51. https://doi.org/10. 1016/j.jhin.2020.01.022 (PMID: 32035997). 